\title{
The Non-Adult Cohort from Le Morne Cemetery, Mauritius: A Snap Shot of Early Life and Death after Abolition
}

\author{
J. APPLEBY, ${ }^{a}$ T. K. SEETAH, ${ }^{\mathrm{a}, \mathrm{c}, \mathrm{d}, \mathrm{g}, \mathrm{h} \text { * }}$ \\ J. F. LAFLEUR, ${ }^{\text {e,f }}$ A. JANOO ${ }^{f}$ AND V. TEELOCK ${ }^{\mathfrak{f}, \mathbf{g}}$ \\ a McDonald Institute for Archaeological Research, Cambridge, United Kingdom \\ b Università Ca' Foscari, Venezia, Italy \\ c ZRC, SAZU, Ljubljana, Slovenia \\ d Department of Archaeology, University of Reading, Reading, UK \\ e Le Morne Heritage Trust Fund, Le Morne, Mauritius \\ ${ }^{f}$ University of Mauritius, Reduit, Mauritius \\ $g$ Truth and Justice Commission, Port Louis, Mauritius \\ h School of Forensic and Investigative Science, University of Central Lancashire, Preston, United Kingdom
}

ABSTRACT The cemetery of Le Morne in Mauritius dates from the 1830s and is thought to contain the remains of slaves, freed slaves or potentially free Madagascans, which in itself has economic and social implications and makes the cemetery all the more intriguing. During 2010, excavations recovered the remains of 11 individuals, of which six were children. Although a small sample, the burials of the non-adults show several interesting features. Two neonates were buried contemporaneously and may have been twins, while a late term foetus in a grave with a young woman may represent an incident of coffin birth. This sample has the potential to cast light on the burial practices of the slave/ex-slave community in Mauritius, about which little is currently known. Copyright @ 2012 John Wiley \& Sons, Ltd.

Key words: diet and health; emancipation; Mauritius; neonatal; non-adult; slavery

\section{Introduction}

The region of Le Morne forms a peninsula on the most south-western tip of Mauritius (Figure 1). It is most famous for the 'Brabant', an inselburg that rises to some $545 \mathrm{~m}$ directly from the shoreline, with an outlook, and sheer drop, to the Indian Ocean on its western facet. The inselburg itself, noted to have one very precarious access point, forms a plateau at its summit. This combination of a single entrance and an area of flat terrain made the Brabant an ideal retreat for runaway slaves and came to be known as the Maroon Republic. The maroonage movement, exemplifying the spirit of resistance to slavery, was commemorated with the inscription of Le Morne as a UNESCO World Heritage Site in 2008, firmly establishing the role of the island as a crucial region for investigations of slavery and maroonage.

\footnotetext{
* Correspondence to: School of Forensic and Investigative Science, University of Central Lancashire, Preston. PR1 2HE, United Kingdom. e-mail: KSeetah@uclan.ac.uk
}

While historical records have revealed much regarding slavery and resistance on Mauritius (Allen 1999, 2001; Teelock 1998, 2009; Vaughan 2005), archaeological research has lagged behind. For numerous reasons, most notable being the dearth of material cultures deriving from slave communities and the very real need for systematic archaeological investigations (which to date have been lacking within the context of slavery and indenture) (Seetah 2010), history has provided the main narrative, relying on careful investigation of existing archives. However, given the types of records kept on slaves, only specific aspects can be studied from this source of evidence, with little chance of gaining a true understanding of life ways or 'resistance' from archival records alone. For this reason, the inscription of Le Morne as a World Heritage Site was unique in that it was the first site to be dedicated based largely on intangible evidence.

The aforementioned situation is effectively reversed with emancipation. Freed slaves literally disappear from the historical record (Teelock, 2005); however, these 


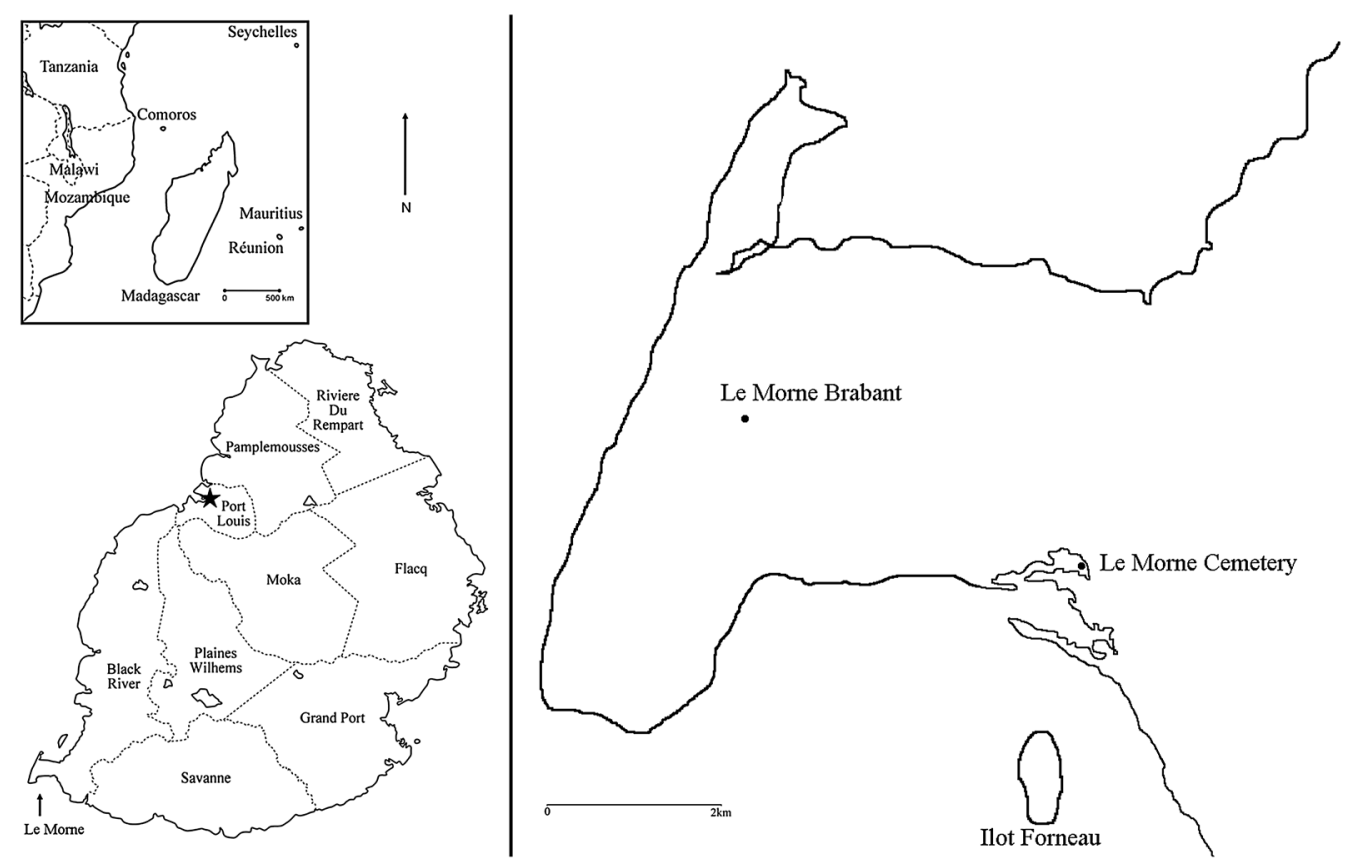

Figure 1. Upper inset: Mauritius and surrounding islands in relation to eastern Africa; lower inset: Mauritius, capital starred, and location of Le Morne. Main: outline of Le Morne and regions mentioned in the text.

communities start to develop their own material culture. While, as slaves, they would have had material goods within a limited capacity, the scale of expression within the context of identity would have greatly increased once free. In Mauritius, emancipation resulted in a migration away from inland sugar estates to coastal fishing communities, and the post-emancipation settlement that developed at Le Morne typifies this move. Within the shadow of the Brabant, a small cemetery, which within local oral tradition had been known as the Malagasy Cemetery, revealed a first for Mauritius: the final resting place of a potential post-emancipation slave community. The article focuses on the first generation of 'free born' descendents in Mauritius, with an exploratory study presented here that centres on burial practice and disease in order to reveal aspects of early life for a small group of individuals that did not enjoy the freedom their ancestors had fought for.

\section{Archaeological investigations at Le Morne}

Since 2009, archaeological work has focused on the exploration of a number of sites that fall within the buffer zone of the Le Morne UNESCO WHS. An initial survey of the cemetery itself revealed approximately five structures, delineated by basalt blocks, and clearly identified as graves; geophysical survey uncovered a further 16 structures. In 2010, a concerted clearance of a larger area surrounding that investigated in 2009 identified 45 structures in total and revealed that two smaller satellite burial areas ostensibly orbited the main cemetery.

During the 2010 campaign, a total of 11 skeletons were recovered from eight graves (Figure 2). Of this skeletal sample, six individuals were non-adults: three perinates and three young children. The perinates were all in double graves: one was buried in Structure 1, the grave of a young adult female (perhaps its mother), and two were placed within a single wooden coffin in a grave of their own (Structure 6).

Although the precise date of the cemetery has not yet been determined by ${ }^{14} \mathrm{C}$ dating, a relative date in the 1830 s is suggested by coins associated with one of the adult graves. This period encompasses the last years of slavery and the first few years after abolition, which took place in Mauritius in 1835. There is the potential that the cemetery was in use before this; however, we can be reasonably confident of this date as the cemetery first appears on regional maps in 1880 (Descubes, 1880), and the region itself only became a stronghold for runaway slaves in the latter part of the $18^{\text {th }}$ century (Allen 1999).

\section{Materials and methods}

The non-adult skeletal remains were analysed in December 2010 by JA according to the recommendations of 


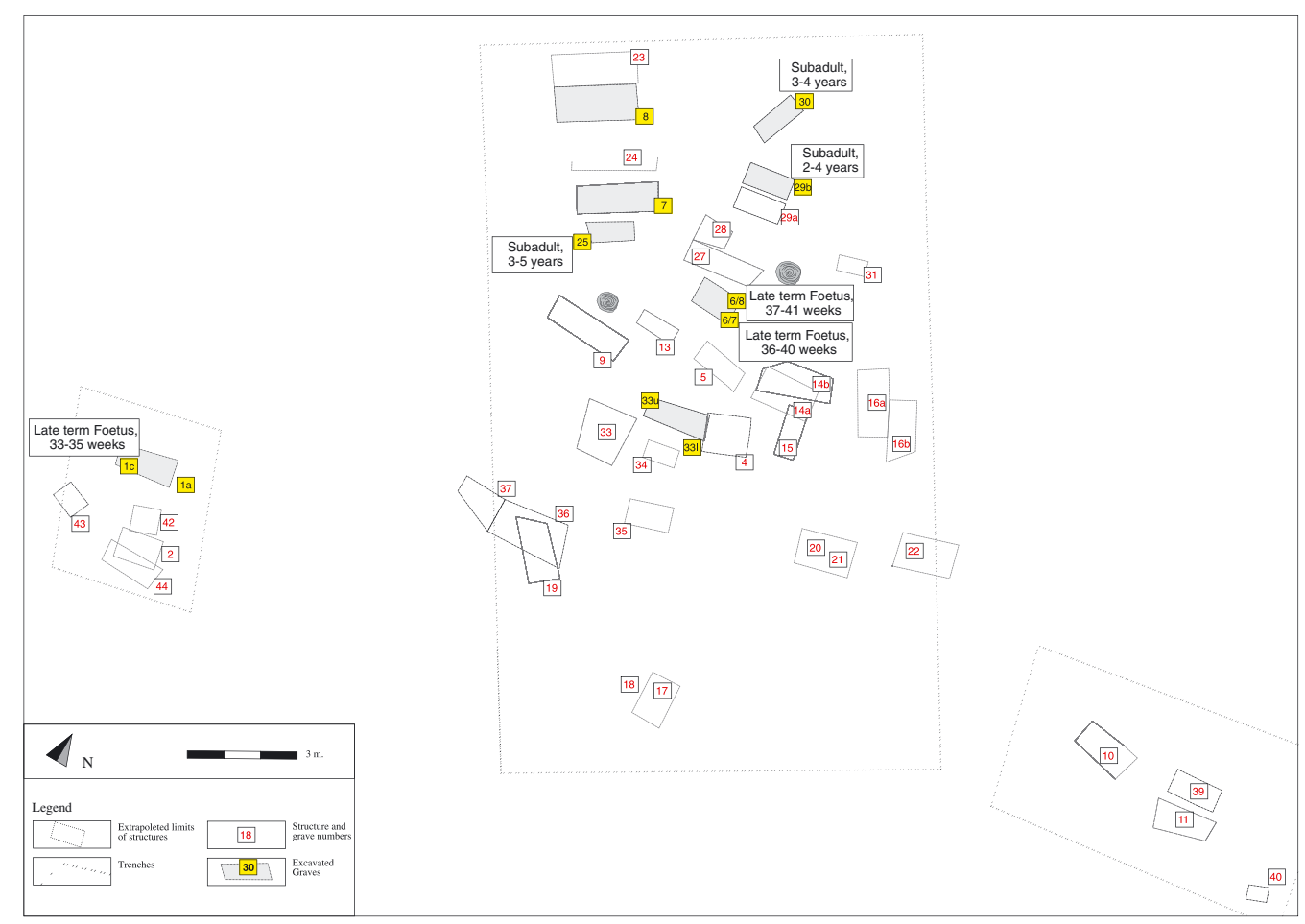

Figure 2. Site plan with position of excavated burials. This figure is available in colour online at wileyonlinelibrary.com/journal/oa.

Buikstra \& Ubelaker (1994). Measurements were taken according to the criteria of Fazekas \& Kósa (1978). Long bones and dentitions were X-rayed in order to assess the presence of periods of growth interruption and to assist in ageing. Because the biological background of this population is not clearly understood, no attempt was made to sex the non-adult remains (for example by measurement of the emergent permanent dentition). Age categories are those suggested by Lewis (2008). Preservation was recorded according to the criteria set out in McKinley (2004), with grades 0-1 recorded as 'good', grades 2-3 as 'moderate' and grades 4-5+ as 'poor'. Fragmentation was recorded as 'moderate' where at least $25 \%$ of surviving long bones were fragmented and as 'significant' when at least $50 \%$ of surviving long bones were fragmented.

\section{Results}

\section{Preservation}

Bone surface preservation and fragmentation showed considerable variability. In general, the perinate skeletons were better preserved than were those of the children (Table 1). All three perinate skeletons were at least $75 \%$ complete with generally good surface preservation, although in some cases, the long bones and in all cases the crania were highly fragmented. In contrast, the skeletons of the three slightly older non-adults were at best moderately well preserved and two were substantially incomplete. Surface damage was often more marked on the posterior surfaces of the bones, and the ends of long bones were frequently

Table 1. Preservation, fragmentation and completeness of non-adult skeletons from the Le Morne cemetery

\begin{tabular}{llllr}
\hline Structure & Age group & Preservation & Fragmentation & Completeness (\%) \\
\hline 1 & Perinate & Good & Moderate & $75+$ \\
$6 / 7$ & Perinate & Good & Moderate & $75+$ \\
$6 / 8$ & Perinate & Moderate-good & Significant & $75+$ \\
25 & Child & Moderate & Significant & $50-75$ \\
29 & Child & Moderate & Significant & 100 \\
30 & Child & Poor & & $25-50$ \\
\hline
\end{tabular}


damaged. Together with frequent breakage of the long bones, this limited the measurements that could be taken, which has implications for the calculation of skeletal age.

The most poorly preserved skeleton was from Structure 30. While most graves had a depth of around $90 \mathrm{~cm}$, Structure 30 was $120 \mathrm{~cm}$ deep. This meant that the skeleton was below the level of the present day high water at spring tides, and it seems likely that this had contributed to the destruction of the bone.

\section{Perinatal individuals}

Ageing techniques were designed to maximise the information that could be gleaned from the sample given the fragmentary nature of most of the skeletons. For the perinates, long bone diaphysis lengths were compared to the charts produced by Fazekas \& Kósa (1978). In addition, both linear and logarithmic regression equations were used, according to the recommendations of Scheuer et al.. (1980; Table 2).

Ageing by both linear and logarithmic regression equations produced consistent results, both for different bones using the same technique and for the same bone using the alternative technique. The Fazekas and Kosa method tended to overage in comparison to the regression techniques by a week or two, a difference that is not significant given the degree of variation encompassed by each.

Most of the applied age calculations for the perinate from structure 1 gave an age of between 33 and 35 weeks gestation, making it approximately one month premature (Table 2). At this stage, it is possible that it could have been born alive, although to survive it would have required very careful care, something that was probably an impossibility in rural $19^{\text {th }}$-century Mauritius. A stillbirth is the most likely explanation, but it is also possible that the foetus underwent coffin birth due to the decomposition process of the mother. This might explain its position between the legs of the female skeleton (Figure 3 ), which exactly mirrors a case of coffin birth from 1930s Poland (Panning 1940).

The perinates from Structure 6 both represent almost full-term or full-term pregnancies (different aging methods gave results between 36 and $40+$ weeks, with the majority falling between 38 and 40 weeks; Table 2). Their placement in the same grave and within a single coffin gives rise to the interesting possibility that they may have been twins. Twin burials have only rarely been reported within the archaeological record: a twin burial dating to the Upper Palaeolithic has been identified at Krems-Wachtberg in Austria (Einwöger et al. 2006), while later prehistoric examples have recently

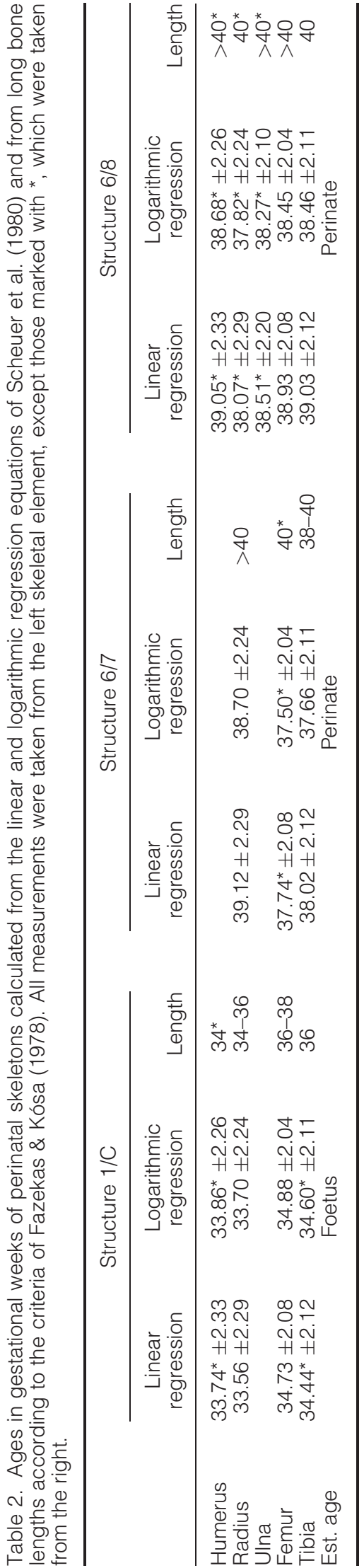

Int. J. Osteoarchaeol. 24: 737-746 (2014) 


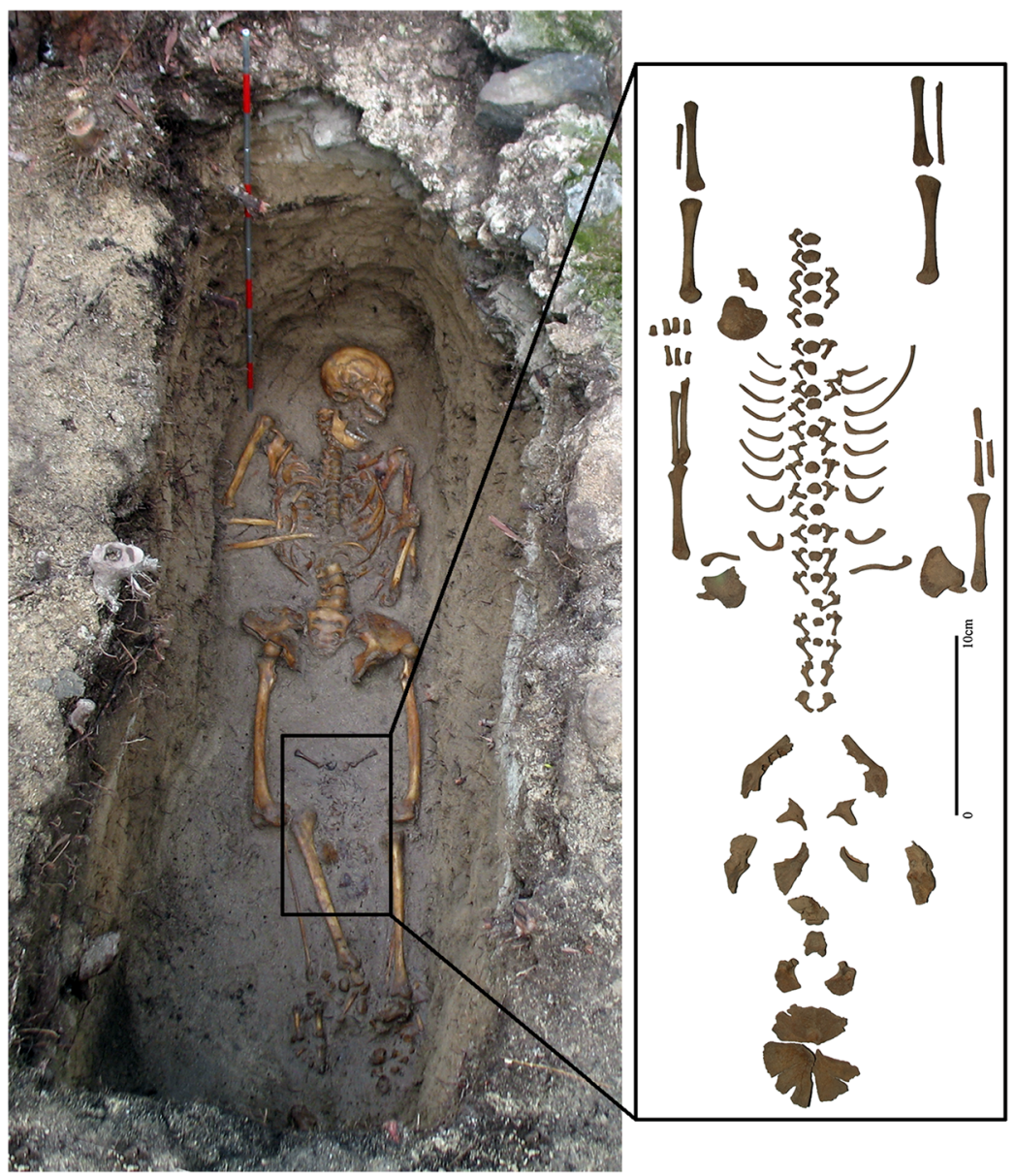

Figure 3. Inset: recovered foetal bones from Structure 1. Main: skeletons in situ. This figure is available in colour online at wileyonlinelibrary.com/journal/oa.

been reported from Olèrdola in Spain (Crespo et al. 2011) and Ochtendung in Germany (Flohr 2012). In order to determine whether the two infants from Le Morne were also a twin burial, or merely represented the burial of two unrelated infants, it was necessary to investigate both the skeletons themselves, and their positioning within the grave (cf. Duday, 2009).

Measurements of the two foetuses were compared to determine the amount of difference between them (Table 3). In order to provide a direct comparison, these were only included where bones from the same side were available from both individuals. There was generally very little difference between the two individuals. Individual 6/8 was slightly larger in all of the postcranial measurements taken, but very slightly smaller on the size of the occipital. This latter difference is so small $(0.4 \mathrm{~mm}$ in width and $0.1 \mathrm{~mm}$ in length) that it is unlikely to be meaningful. In the postcranial elements, the smallest difference was $0.9 \mathrm{~mm}$ (both femoral and tibial diameters) and the largest $2.4 \mathrm{~mm}$ (tibia length). There is an apparent relationship between the size of the measurement and the degree of difference. Thus, the largest differences are between the longest measurements (femur and tibia lengths).

Table 3. Comparative measurements in $\mathrm{mm}$ for the perinates from Structure 6. ${ }^{*}=$ slight imprecision caused by either erosion or the need to reconstruct the bone not considered sufficiently severe to prevent the measurement from being taken.

\begin{tabular}{lccc}
\hline & Structure 6/7 & Structure 6/8 & Difference \\
\hline $\begin{array}{l}\text { Length of basilar part } \\
\text { of occipital }\end{array}$ & 12.0 & 11.9 & -0.1 \\
Width of basilar part & 14.5 & 14.1 & -0.4 \\
$\quad$ of occipital & 28.4 & 30.2 & 1.8 \\
llium width (left) & 15.1 & 16.5 & 1.4 \\
Humerus width (right) & 5.1 & 6.1 & 1 \\
Humerus diameter (right) & $73.2^{*}$ & 74.6 & 1.4 \\
Femur length (right) & $6.3^{*}$ & 7.2 & 0.9 \\
Femur diameter (right) & 63.1 & 65.5 & 2.4 \\
Tibia length (left) & $5.8^{*}$ & 6.7 & 0.9 \\
Tibia diameter (left) & & & \\
\hline
\end{tabular}

Int. J. Osteoarchaeol. 24: 737-746 (2014) 
It is common that there will be some size difference between twins (in a study by Demissie et al. (2002) 15\% of twins had a weight discordancy of at least $20 \%$ at birth). The slight variation in size seen in the perinates from Structure 6 is therefore well within the normal range of variation. In and of itself, though, this is not sufficient to prove that these babies were born at the same time and from the same mother. DNA evidence might be able to cast light on the relationship, but unfortunately, it has not proved possible to extract DNA from the Le Morne skeletons at this time. Therefore, evidence from the grave itself is the only available source to show that the perinates were buried at the same time and are likely to be twins.

The placement of two bodies within a single grave is not in itself sufficient to prove contemporaneous death. Graves can be re-opened to insert later burials, and remains can be redeposited from other primary grave locations. In order to determine whether this could have occurred, the structure of the grave and the coffin, and the patterns of bodily decomposition must be observed. The Structure 6 grave was $0.8 \times 0.5 \mathrm{~m}$ in size and covered with a rectangle of basalt stones. There is no evidence for more than one phase of grave digging. Within the grave, a single coffin could be identified from the position of coffin nails, and this contained the bodies of both perinates, placed in an extended supine position. Both are in anatomical order, and there is no indication that either body was at all decayed at the point that it was placed in the ground. Although the hands and feet are not visible in the excavation photograph, they were in correct anatomical position when the bodies were uncovered. This means that the perinates must have died at around the same time, since decomposition would begin rapidly in a hot environment such as that on Mauritius, and if one of the bodies had partially decomposed when it was placed in the coffin, there would be evidence for this in the form of loss of anatomical order at the labile articulations such as the hands and feet (Duday, 1990). It therefore seems most likely that these were twins who died in the perinatal period, rather than two unrelated babies placed in the same grave.

Although the identity of the burial community at Le Morne is not known for certain (DNA analysis was unsuccessful, and isotopic analysis was consistent with a local origin; Seetah et al., .), their most likely ancestry is in Africa or Madagascar. Interestingly, African communities today have the highest levels of twin births worldwide, reaching up to 45 sets of twins per 1000 births. Of these, $90 \%$ are dizygotic. Twin pregnancies have a higher rate of complications than singleton pregnancies, bringing risk both to the mother and to the babies. The most common complication is preterm birth: the average gestational age of twins at birth is 37 weeks, compared with 40 weeks in singletons (Fletcher, 2009). Premature birth is one reason that twins born in modern societies with good medical care still have higher morbidity and mortality than singletons. The calculated gestational age of the twins from Le Morne is around 38-40 gestational weeks. Thus, if they were born at the average age for twins, they may have survived for up to two weeks outside the womb. Unfortunately, there is no way to determine whether this was actually the case in this instance.

Caring for twins involves a significantly greater investment of time and resources than does caring for a single infant, and this can have a significant effect on their ability to survive. Mothers of twins must provide twice as much food and twice as much care to babies who are frequently born prematurely and thus underweight, making them more vulnerable to infection. There are various accounts from Mauritius of female slaves being given inadequate time to care for their babies; Anthony Barker (1996) cites several textual examples of slave mothers who complained that they did not have time to nurse their single babies. The problem would have been twice as severe in mothers of twins. Insufficient nursing time may have been compounded by the fact that time spent in breastfeeding infants would have decreased the time the mother could spend on preparing and eating her own food. Malnourished mothers would have found it difficult to produce sufficient milk for two babies simultaneously. Even if the Le Morne cemetery postdates abolition, or was created by freed slaves, the birth of twins would have placed difficult demands upon the mother.

\section{Older non-adults}

Age estimations for the three older non-adult skeletons were carried out from the development of the dentition (Ubelaker, 1978), the length of the long bones and clavicle (Maresh, 1970; Black \& Scheuer, 1996) and from the fusion of the vertebral column (Scheuer \& Black, 2000) in declining order of priority (Table 4). This reflects the increased accuracy of dental over long-bone ageing. Generally, all three methods gave overlapping ages, with occasional small differences in oldest or youngest age. For the two older children, the clavicle was the only postcranial element for which age could be determined from length. This tended to overage by about one year in comparison to the

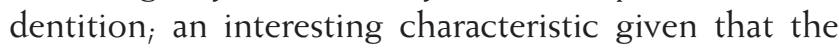
discrepancy is in the opposite direction to what would 
Table 4. Ages in years of child skeletons calculated from individual long bone (Maresh, 1970) and clavicle (Black \& Scheuer, 1996) lengths, from the development of the dentition (Ubelaker, 1978) and from the degree of vertebral fusion (Scheuer \& Black, 2000)

\begin{tabular}{llll}
\hline & Structure 25 & Structure 29 & Structure 30 \\
\hline Clavicle & $4-6$ & $2-3$ & $4-6$ \\
Ulna & & $2-2.5$ & \\
Radius & 2 & \\
Femur & $1.5-2.5$ & \\
Tibia & $1.5-2$ & \\
Fibula & & 2 & \\
Dentition & $4 \pm 12$ months & $2 \pm 8$ months & $4 \pm 12$ months \\
Vertebral fusion & $3-4$ & 2 & $3-5$ \\
Assigned age & $3-5$ & $1.5-2.5$ & $3-5$ \\
& & & \\
\hline
\end{tabular}

usually be expected (difficult environmental conditions typically leading to retardation of long bone growth compared to the dentition (Smith 1991)). Black and Scheur's study of the growth of the clavicle included a number of age groups with very small numbers in the reference sample (for example, only two individuals aged five to six were included; Black \& Scheuer, 1996: Table 3). This means that it is likely that Black and Scheur's results do not include the full range of normal variation for each age group. On this basis, the clavicle was not included in the calculation of 'assigned age' for this sample. For the remaining individual (Structure 29), the three ageing techniques matched well.

The close relationship between dental development stage and postcranial measurements other than the clavicle suggests that the children buried at Le Morne were not subject to reduced growth caused by illness or disease. Further analysis of the skeletons for evidence of periods of growth interruption confirms this picture: there were no hypoplastic lesions on the teeth, and no Harris lines were visible on the long bones. Given the young age of these children, it is not likely that any Harris lines would have been remodelled. Cribra orbitalia and porotic hyperostosis, which have been linked with anaemia due to dietary deficiency (although this is now thought to relate to vitamin B12 and not irondeficiency as has previously been suggested), disease or genetic conditions (Walker et al. 2009), are also absent in the Le Morne child skeletons.

The often-quoted osteological paradox (Wood et al., 1992) states that skeletons may be free of pathological conditions either where individuals were healthy, or where they were so stressed that death followed illness before skeletal lesions could develop. The Le Morne skeletons are likely to belong to slaves or ex-slaves, and as such, it is tempting to speculate that they died before diseases/non-specific stress factors could show up on the skeleton; however, it is difficult to argue that the skeletons from Le Morne represent a systematically stressed population, given that dental ages are younger than ages derived from postcranial measurements. If the population was subject to serious nutritional deficiency and/or morbidity, it is unlikely that that would be the case (especially as this seems to be a short population in adulthood; Seetah et al., in prep). The most parsimonious explanation, therefore, is that these children had an adequate diet and died from infectious diseases. Although there were no major epidemics in Mauritius in the 1830s (repeated outbreaks of cholera and malaria were a fact of life only from the 1850s and 1860 s, respectively), infectious diseases such as dysentery would have been a constant presence.

The only skeletal pathologies observed on the child skeletal remains from Le Morne were carious lesions on the upper central deciduous incisors of the 1.5-2.5 year old child from Structure 29 (three anterior mandibular teeth were lost post mortem, but caries were absent from the rest of the deciduous dentition). No evidence for either hypoplastic lesions or hypocalifications could be observed on the teeth of this individual. In the absence of such defects, this is a young age for the teeth to be affected by caries, especially the incisors. In modern populations, early childhood caries of the maxillary incisors have been linked to feeding practices that increase the exposure of the teeth to simple carbohydrates (Hallet \& O'Rourke 2006). The identification of carious lesions in the anterior teeth of such a young individual here may therefore indicate a weaning diet high in simple carbohydrates. There were no sugar plantations in the area around Le Morne during the 1830 s, and sugar cane is unlikely to have been available to poor communities such as this (slaves could be punished for consuming sugar cane). A large part of the slave diet was, though, made up of carbohydraterich food such as maize and manioc (Telfair, 1830), and the use of these as weaning foods may explain the presence of caries on such a young child.

\section{Discussion}

Perinatal and child skeletons are present in the Le Morne sample at a higher ratio than adults, though as Figure 2 illustrates, many more structures remain to be excavated. Although this is a very small sample and therefore not amenable to statistical analysis, this is an interesting pattern, given the tendency of infants and children to be under-represented in archaeological cemetery assemblages (Lewis, 2008).

Int. J. Osteoarchaeol. 24: 737-746 (2014) 
During the early 19th century at Le Morne, a number of factors are likely to have contributed to high infant and child mortality. It is unlikely that mothers would have had access to good standards of medical care, and access to doctors may have been neither available nor desired. In the later period of indentured labour in Mauritius, there were huge problems in providing medical treatment on plantations: often there were no hospitals, it was difficult for doctors to travel to many parts of the island and even when health care was provided, indentured labourers often preferred to avoid it in favour of folk treatments (Boodhoo, 2010). Such problems would have been equally, if not more, likely under slavery. Without medical assistance, the risks associate with childbirth would have been great, especially amongst malnourished mothers. Cramped and dirty living conditions are also likely to have contributed to disease and death amongst non-adults.

The presence of twin neonates may be related to the difficulties associated with both giving birth to and caring for two infants in a slave context, however, there is another, more sinister possible explanation behind the double burial of twins. In parts of Madagascar, and Africa (Piontelli, 2008), it is believed that twins are the incarnation of evil spirits, and that to allow them to live risks bringing harm to the entire community. Twin infanticide on Madagascar has been described in various anthropological texts from the time of van Gennep (1904) to the present day (Piontelli, 2008). Given this possibility, the perinate skeletons were examined for evidence of violence in the form of perimortem fractures. Many of the long bones were fractured, and the skulls were fragmentary; however, the fracture surfaces were usually rough, and the fracture margins lacked the sharp margins of perimortem fractures. It is therefore most likely that the bones were fractured when the coffin decayed and the surrounding sediment collapsed into the burial space.

Finding direct evidence of infanticide on perinatal skeletal remains is notoriously hard (Lewis, 2008). For example, strangulation may be identified on adult bones from the fracture of the hyoid, but in neonates the hyoid has only commenced ossification (Lewis, 2008). Drowning is another possible method of disposal that would leave no trace on the skeleton. Both of these techniques have been recorded in Madagascan groups practising twin infanticide. Van Gennep (1904) reports that amongst the Antambahoaka of Southeast Madagascar, when a woman gave birth to twins, they were immediately given to a local sorcerer who strangled them and threw the bodies into a swamp. The family were then able to mourn the loss of the children. In a discussion of twin infanticide in an unspecified social group in Madagascar in the 1990s, Piontelli (2008) states that women would frequently give birth next to canals or the sea. The mother would kill twins: either by drowning, abandoning them or placing them into a container that was launched out to sea. In contrast, stillborn and miscarried babies were placed in water-filled jars.

The lack of formal burial afforded to twins in Madagascan communities practising twin infanticide is clearly not paralleled in the careful disposal of the twins at Le Morne, placed within a coffin in a well-constructed grave. Furthermore, the possibility that the twins, if premature, survived for a short period of a week or two would again suggest that these were not the victims of infanticide.

\section{Conclusion}

The remains of the non adult cohort from Le Morne, although small in number, give us an opportunity for the first time to directly investigate living conditions and cultural practices amongst the rural, possibly slave, communities of $19^{\text {th }}$ century Mauritius without the distorting lens of accounts written by either slave owners or abolitionists. Historical sources suggest that life may have been extremely hard; while this is not borne out by the non-adult skeletons, which show no evidence of dietary insufficiency or other ill health, one cannot escape the fact that these individuals died in early life, seemingly supporting the textual accounts. The presence of twin perinates within one of the graves is rather enigmatic: they may represent natural neonatal mortality or, an arguably less probable alternative, the results of a culturally determined practice of infanticide.

Despite its limitations, this assemblage has already enriched our current understanding of the region and associated communities. Clearly, as so often the case, more questions arise than are answered ${ }_{i}$ however, the narrative now has another line of evidence from which to draw inference regarding a group that has much to offer in term of understanding past human interactions at a crucially important global transition: from slave to free labour. Perhaps most important is the fact that we finally have useful material to study; numerous burial and cemetery sites exist on Mauritius that hint at the nuanced and complex social relationships evident in death. Slaves are at times buried with their master, or on the periphery of the master's cemetery, in some cases with decorative tombs. Our understanding of the relationship between slave and master, indeed, the concept of slavery, needs careful evaluation through the lens of osteoarchaeology and associated burial practice. Equally important is the dynamic between forced and 
free labour as exemplified in the ways slaves, indentured labourers and free / freed peoples treated their dead. Mauritius serves as a valuable region for such investigations and the small cohort outlined in this article potentially has much to contribute within a comparative dimension in future research.

\section{Acknowledgments}

The authors gratefully acknowledge the support of the Truth and Justice Commission (TJC), particularly Prof. Alex Boraine, Mr Benjamin Moutou, Mrs Colette Le Chartier, Mr Allan Charlot and Mr Satyendra Peerthum. From the Le Morne Heritage Trust Fund (LMHTF), our sincere thanks to the Acting Chairperson, Mr Mathieu Lacle, and to Mrs Nelly Ardill and Mr Thierry Le Breton from SOS Patrimoine, for financial and logistical support. Our thanks to Mr Beebeejaun of the Mauritius Museum Council, Ms Sheila Thanoo of National Heritage Fund and Mr Choonee, Minister for Arts and Culture. Our grateful thanks to Prof. Konrad Morgan, VC of UoM, for providing logistical support and facilities to study the remains. Rose Ferraby provided geophysical expertise in 2009; students from the UoM, UCLan and local participants from Le Morne provided essential site support, for which we are very grateful. Funding for this research has been provided by, and gratefully received from: the TJC, LMHTF, SOS Patrimoine, the University of Mauritius, the US State Office (Mauritius), The British Academy (SG-54650 / SG-10085), The British Council (Darwin Now Award), The McDonald Institute for Archaeological Research and the University of Central Lancashire (UK).

The authors thank three anonymous reviewers who contributed to improving an earlier draft of this article.

\section{References}

Allen R. 1999. Slaves, Freedmen, and Indentured Laborers in Colonial Mauritius. Cambridge University Press: Cambridge.

Allen R. 2001. Licentious and unbridled proceedings: the illegal slave trade to Mauritius and the Seychelles during the early nineteenth century. The Journal of African History 42: 91-116.

Barker A. 1996. Slavery and Antislavery in Mauritius, 1810-1833: the conflict between economic expansion and bumanitarian reform under British rule. St Martin's Press: New York.

Black SM, Scheuer JL. 1996. Age changes in the clavicle: from the early neonatal period to skeletal maturity. International
Journal of Osteoarchaeology 6: 425-434. DOI: 10.1002/(SICI) 1099-1212(199612)6:5 < 425::AID-OA287 > 3.0.CO;2-U

Boodhoo R. 2010. Health, Disease and Indian Immigrants in Nineteenth Century Mauritius. Port Louis: Aapravasi Ghat Trust Fund.

Buikstra JE, Ubelaker DH. 1994. Standards for Data Collection from Human Skeletal Remains. Arkansas Archeological Survey Research Series 44. Fayetteville: Arkansas Archaeological Survey.

Crespo L, Subira ME, Ruiz J. 2011. Twins in Prehistory: The case from Olèrdola (Barcelona, Spain; s. IV II BC). International Journal of Osteoarchaeology 21, 751-756. DOI: $10.1002 /$ oa. 1169 .

Demissie K, Ananth CV, Martin J, Hanley ML, MacDorman MF, Rhoads GG. 2002. Fetal and Neonatal Mortality Among Twin Gestations in the United States: The Role of Intrapair Birth Weight Discordance. Obstetrics and Gynecology 100(3), 474-480. DOI: 10.1016/S0029-7844 (02)01951-8.

Descubes A. 1880. Map of the Island of Mauritius. Dept. of Public Works, : Mauritius.

Duday H. 1990. L'Anthropologie « de terrain »: reconnaissance et interprétation des gestes funéraires. Bulletins et Mémoires de la Société d'antbropologie de Paris, Nouvelle Série, tome 2 fascicule 3-4: 29-49. DOI: 10.3406/bmsap.1990.1740

Duday H. 2009. The Archaeology of the Dead: Lectures in Archaeothanatology. Oxford: Oxbow.

Einwöger $T$, Friesinger $H$, Händel $M$, NeugebauerMaresh C, Simon U, Teschler-Nicola M. 2006. Upper Palaeolithic Infant Burials. Nature 444: 285. DOI: 10.1038/444285a

Fazekas IG, Kósa F. 1978. Forensic Fetal Osteology. Budapest: Akadémiai Kiadó.

Fletcher GE. 2009. Multiple Births. Emedicine. http:// emedicine.medscape.com/article/977234-overview\#a0199. Accessed 06.02.2012

Flohr S. 2012. Twin Burials in Prehistory: A Possible Case from the Iron Age of Germany. International Journal of Osteoarchaeology Early View. DOI 10.1002/oa.2236

Hallet KB, O'Rourke PK. 2006. Pattern and Severity of Early Childhood Caries. Community Dentistry and Oral Epidemiology 34: 25-35.

Lewis ME. 2008. The Bioarchaeology of Children. Perspectives from Biological and Forensic Antbropology. Cambridge: Cambridge University Press.

Maresh MM. 1970. Measurements from roentgenograms. In Human Growth and Development, RW McCammon (ed.). Springfield: Charles C. Thomas; 157-200.

McKinley JI. 2004. Compiling a skeletal inventory: disarticulated and co-mingled remains. In Guidelines to the Standards for Recording Human Remains. Southampton and Reading: BABAO and the IFA; 14-17.

Panning G. 1940. Sarggeburt. International Journal of Legal Medicine 34(1): 257-264. DOI: 10.1007/BF01793811

Piontelli A. 2008. Twins in the World: the legends they inspire and the lives they lead. Basingstoke: Palgrave Macmillan.

Scheuer L, Black S. 2000. Developmental Juvenile Osteology. Amsterdam: Elsevier. 
Scheuer JL, Musgrave JH, Evans SP. 1980. The estimation of late fetal and perinatal age from limb bone length by linear and logarithmic regression. Annals of Human Biology 7: 257-265. DOI: 10.1080/03014468000004301

Seetah K. 2010. 'Our Struggle'. Mauritius: an exploration of colonial legacies on an island paradise. SHIMA The International Journal for Island Cultures 4: 99-112.

Seetah K, Calaon D, Čaval S, Pluskowski A, Appleby J, Lightfoot E. in prep. In prep. Of slaves and freedom: investigating legacies of post-medieval colonialism through the lens of archaeology.

Smith BH. 1991. Standards of human tooth formation and dental age assessment. In Advances in Dental Antbropology, MA Kelly, CS (eds.). New York: Wiley-Liss; 143-168.

Teelock V. 1998. Bitter Sugar. Moka: Mahatma Gandhi Institute.

Teelock V. 2005. Breaking the wall of silence: slavery in Mauritian historiography. Radical History Review 91: 104-109. DOI: 10.1215/01636545-2005-91-104

Teelock V. 2009. Mauritian History. Moka: Mahatma Gandhi Institute.
Telfair C. 1830. Some Account of the State of Slavery at Mauritius Since the British Occupation in 1810; in Refutation of Anonymous Charges Promulgated Against Government and That Colony. London: James Ridgway.

Ubelaker DH. 1978. Human Skeletal Remains: Excavation, Analysis and Interpretation. Washington DC: Smithsonian Institute Press.

van Gennep A. 1904. Tabou et Totémisme à Madagascar, etude descriptive et théorique. Paris: Bibliothèque de l'École des Haut Études.

Vaughan M. 2005. Creating the Creole Island. Durham NC: Duke University Press.

Walker PL, Bathurst RR, Richman R, Gjerdrum $\mathrm{T}$, Andrushko VA. 2009. The causes of cribra orbitalia and porotic hyperostosis: A reappraisal of the iron-deficiency anemia hypothesis. American Journal of Physical Antbropology 139(2): 109-125.

Wood JW, Milner GR, Harpending HC, Weiss KM. 1992. The Osteological Paradox: Problems of Inferring Prehistoric Health from Skeletal Samples. Current Antbropology 33(4): 343-70. DOI: 10.1086/204084 